\title{
Synthesis and Atypical Antipsychotic Profile of Some 2-(2-Piperidinoethyl)benzocycloalkanones as Analogues of Butyrophenone ${ }^{\dagger}$
}

\author{
José A. Fontenla,", Javier Osuna, ${ }^{\ddagger}$ Elizabeth Rosa, ${ }^{\ddagger}$ Ma Elena Castro, ${ }^{\ddagger}$ Tomás G-Ferreiro, ${ }^{\ddagger}$ Isabel Loza-García, ${ }^{\ddagger}$ \\ José M. Calleja, ${ }^{\ddagger}$ Ferrán Sanz, ${ }^{\S}$ Jesús Rodríguez, ${ }^{\S}$ Enrique Raviña, ${ }^{\perp}$ Javier Fueyo, ${ }^{\perp}$ Christian F-Masaguer, ${ }^{\perp}$ \\ Antonio Vidal, $\perp$ and María L. de Ceballos"

\begin{abstract}
Department of Pharmacology, Faculty of Pharmacy, and Department of Organic Chemistry, Laboratory of Pharmaceutical Chemistry, University of Santiago de Compostela, 15706 Santiago de Compostela, Spain, Department of Medical Informatics, Institut Municipal d'Investigació Mèdica (UAB), c/Doctor Aiguader, 80, 08003 Barcelona, Spain, and Department of Neuropharmacology, Cajal Institute, CSIC, 28002 Madrid, Spain
\end{abstract}

Received January $27,1994^{\otimes}$

Four new 2-(2-piperidinoethyl)benzocycloalkanone derivatives, 20-23, were prepared and evaluated as potential antipsychotic agents in receptor binding assays for dopamine (DA) and $5-\mathrm{HT}_{2 \mathrm{~A}}$ receptors and in functional and behavioral screens. Their affinities for $\mathrm{D}_{2}$ receptors $\left(K_{\mathrm{i}}^{\prime} \mathrm{s}\right.$ in the nanomolar range: $\left.46.7-70.7\right)$ and $\mathrm{D}_{1}$ receptors $\left(K_{\mathrm{i}}\right.$ 's in the micromolar range: $1.09-$ $2.81)$ were slightly lower than that showed by haloperidol ( $K_{\mathrm{i}}$ 's in the nanomolar range: 5.01 and 97.72 for $\mathrm{D}_{2}$ and for $\mathrm{D}_{1}$ receptors, respectively). The ratio of $\mathrm{p} K_{\mathrm{i}}$ 's values $\mathrm{D}_{1} / \mathrm{D}_{2}$ showed that the new molecules are more $\mathrm{D}_{2}$-selective than haloperidol. In contrast, in the $\left[{ }^{3} \mathrm{H}\right]$ ketanserin binding assays the new compounds had greater affinity for $5-\mathrm{HT}_{2 \mathrm{~A}}$ receptors $\left(\mathrm{p} K_{\mathrm{i}}^{\prime} \mathrm{s}\right.$ 7.89-8.60) than haloperidol ( $\mathrm{p} K 1$ 7.70) and in functional studies, endothelium-stripped aorta rings, the $\mathrm{p} A_{2}$ values (6.75-8.12) were slightly lower than that of ketanserin (8.87) in suppresing serotonin-induced contractions. The $\mathrm{p} K_{\mathrm{i}}^{\prime} \mathrm{s}$ for $\mathrm{D}_{2}$ binding (and to a lesser extent $\mathrm{p} K_{\mathrm{i}}^{\text {' }} \mathrm{s}$ for $\mathrm{D}_{1}$ binding) tend to be greater among typical (classical) than among atypical antipsychotics, while these two classes of antipsychotics exhibit no difference with regard to $\mathrm{p} K_{\mathrm{i}}$ 's for 5 -HT $\mathrm{H}_{2 \mathrm{~A}}$ receptors. The ratios of $\mathrm{p} K_{\mathrm{i}}$ 's for $5-\mathrm{HT}_{2 \mathrm{~A}} / \mathrm{D}_{2}$ receptors may be useful for rapid screening of new compounds, and its potential induction of extrapyramidal symptoms (ratio values $>1.12$ were predictive of an atypical antipsychotic profile). The new molecules had a ratio value in the range 1.081.20 , while haloperidol showed a ratio of 0.93 . In the behavioral screening tests, the new molecules showed antagonist activity of amphetamine-inducing hyperactivity and apomorphineinduced climbing (predictive tests for antipsychotic activity). In the catalepsy test (predictive test for induction of extrapyramidal symptoms), the values obtained were in accordance with an atypical antipsychotic drugs profile.

\section{Introduction}

Administration of neuroleptics such as chlorpromazine or haloperidol is still the only effective treatment of a variety of psychiatric disorders (schizophrenia, the manic phase of manic-depressive psychosis). However, most neuroleptics (also called "classical antipsychotics") have two major drawbacks. First, they can induce extrapyramidal symptoms (sometimes at the start of treatment or following months/years of therapy). Second, negative symptoms (such as blunted affectivity, emotional withdrawal, apathy, and motor retardation) respond poorly in most patients. Since the 1970 s, atypical (nonclassical) antipsychotics which have no extrapyramidal side effects and are effective against negative symptoms have been available. The prototype of this group, clozapine, whose atypical activity has been

† This paper has been presented, in part, to the XIIth International Symposium on Medicinal Chemistry, Basel (Switzerland), Sept 92 (Proceedings volume $\mathrm{p} \mathrm{178).}$

* Author for correspondence: José A. Fontenla, Department of Pharmacology, Faculty of Pharmacy, University of Santiago de Compostela, 15706 Santiago de Compostela, Spain. Tel (34) 81594630 . Fax (34) 81594595.

¥ Department of Pharmacology, Faculty of Pharmacy, University of Santiago de Compostela.

$\$$ Department of Medical Informatics, Institut Municipal d'Investigació Mèdica (UAB).

$\perp$ Department of Organic Chemistry, Laboratory of Pharmaceutical Chemistry, University of Santiago de Compostela.

"Department of Neuropharmacology, Cajal Institute.

* Abstract published in Advance ACS Abstracts, June 15, 1994. attributed classically to its anticholinergic activity, was withdrawn because of its ability to induce agranulocytosis, but in view of the lack of alternatives has since been reintroduced into clinical practice, with the restriction that its use must be accompanied by rigorous blood monitoring. ${ }^{1-3}$

Seeman ${ }^{4-6}$ reported that antipsychotic activity is closely correlated with the ability to block $\mathrm{D}_{2}$ dopamine receptors but not with $D_{1}$ receptor blockade, although the subsequent development of $D_{1}$-selective agonists and antagonists indicated that $D_{1}$ receptors may also be involved in the clinical response to antipsychotics. ${ }^{7-9}$ For 10 years or more, the two subtype classification could accommodate most of the activities attributed to the dopaminergic system. However, this has changed and the dopamine receptors have been reviewed recently. ${ }^{10,11}$ Molecular cloning techniques have permitted the identification of several dopamine receptors called $D_{1}, D_{2}$ $\left(D_{2 L}\right.$ and $\left.D_{2 S}\right), D_{3}, D_{4}$, and $D_{5} / D_{1 B}$, recently grouped together into two subfamilies: $D_{1}$-like $\left(D_{1 A}\right.$ and $\left.D_{5} / D_{1 B}\right)$ and $\mathrm{D}_{2}$-like $\left(\mathrm{D}_{2}, \mathrm{D}_{3}\right.$ and $\left.\mathrm{D}_{4}\right)$ subfamilies.

The $\mathrm{D}_{1}$-like receptors exhibit very similar ligand binding properties: high affinity for benzazepines (SCH 23390, SKF 38393) and low affinity for butyrophenones (spiperone, haloperidol) and substituted benzamides (sulpiride). An interesting difference between the $D_{1}$ like receptors is that the $\mathrm{D}_{5} / \mathrm{D}_{1 \mathrm{~B}}$ receptor binds dopamine with a higher affinity than does the $D_{1 A}$ receptor. 


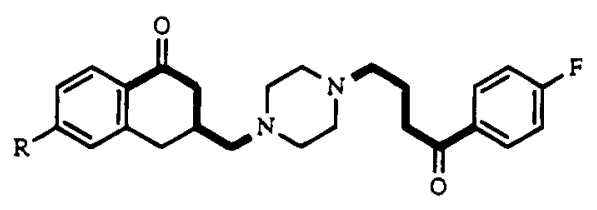

$R=H \quad 1$

$R=F \quad 2$

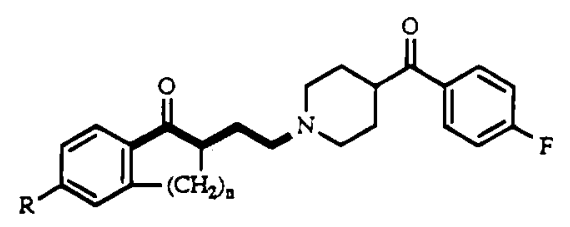<smiles>O=C1C[C@H](CN2CCC(C(=O)c3ccc(F)cc3)CC2)Cc2ccccc21</smiles>

3<smiles>O=C(CCCN1CCC(O)(c2ccc(Cl)cc2)CC1)c1ccc(F)cc1</smiles>

Figure 1.

All three $D_{2}$-like receptors possess high affinity for butyrophenones such as spiperone and haloperidol and low affinity for benzazepines such as SKF 38393. The $\mathrm{D}_{4}$ receptor exhibits relatively high affinity for the atypical neuroleptic clozapine; this has led to speculation that the $D_{4}$ receptor might be the relevant target of this atypical neuroleptic (for a review of DA receptors, see ref 12 and 13 ).

Clozapine blocks not only dopamine receptors but also $5-\mathrm{HT}_{2 \mathrm{~A}}$ serotonin receptors, and recent findings suggest that its atypical activity may be due to this latter feature. ${ }^{14}$ This hypothesis is supported by clinical evidence that the $5-\mathrm{HT}_{2 \mathrm{~A}}$-blocking capacity of certain antipsychotics reduces extrapyramidal side effects and improves the outcome of negative symptoms. An example is setoperone, a drug with potent $5-\mathrm{HT}_{2 \mathrm{~A}}$-blocking and moderate $\mathrm{D}_{2}$-blocking activity which has proved effective in the treatment of negative symptoms in schizophrenics and also causes few extrapyramidal effects. ${ }^{15}$

In previous papers ${ }^{16,17}$ we have reported the synthesis and antidopaminergic and antiserotoninergic activities of 3-(aminomethyl)tetralones 1-3, which are conformationally restricted butyrophenone structures analogous to haloperidol, 4. As a continuation of that work we have now prepared the 2-(2-aminoethyl)benzocycloalkanones 20-23, which also possess the essential requirements for interaction with DA and serotonin (5HT) receptors. These compounds have two butyrophenone pharmacophores, the (aminoethyl)cycloalkanone moiety and the 4-( $p$-fluorobenzoyl)piperidine fragment. This latter, which has been described as a neuroleptic pharmacophore of similar potency to the butyrophenone portion, ${ }^{18}$ is also an important feature for 5 - $\mathrm{HT}_{2 \mathrm{~A}}$ binding. ${ }^{19}$

On the other hand, it is known that ketanserin $\mathbf{5}$ is the prototypic $5-\mathrm{HT}_{2 \mathrm{~A}}$ receptor antagonist. In the ketanserin molecule is necessary to consider two structural aspects: (a) the quinazolinone moiety is not essential and may be replaced by a pyrimido pyrimidine (e.g., pirenperone 6) or a thienopyrimidine nucleus (e.g., setoperone 7) or abbreviated to a simpler structural aroyl ketone or amide and (b) there is an aromatic binding site that accommodates the aryl portion of the heterocyclic ring. ${ }^{19}$ It is evident that the design of molecules under study satisfy these requirements because they have an aroyl portion that binds the $p$ fluorobenzoyl fragment across an aminoethyl side chain<smiles>O=C(c1ccc(F)cc1)C1CCN(CCn2c(=O)[nH]c3ccccc3c2=O)CC1</smiles><smiles>Cc1nc2ccccn2c(=O)c1CCN1CCC(C(=O)c2ccc(F)cc2)CC1</smiles><smiles>Cc1nc2n(c(=O)c1CCN1CCC(C(=O)c3ccc(F)cc3)CC1)CCS2</smiles>

Figure 2.

partially incorporated in a conformationally restricted cycloalkanone structure.

\section{Chemistry}

Compounds 20-23 were synthesized via the sequence of reactions outlined in Scheme 1. Literature procedures for the preparation of tetralone- and indanoneacetic acids involve condensation with glyoxylic acid in alkaline medium and subsequent reduction with zinc and acetic acid of the resulting alkene acid. ${ }^{20,21}$ Other synthetic routes have been described for preparing these compounds. $^{22-26}$

In this paper, indanone, 5 -fluoroindanone, tetralone, and benzosuberone-2-acetic acids 12-15 were prepared by one of the following methods: (A) aldol condensation with glyoxylic acid in alkaline medium to give 1-oxo2,3-dihydro-indanylidene acetic acid 8 and their 5-fluoro derivative 9, (1-oxo-1,2,3,4-tetrahydro-2-naphthylidene)acetic acid 10, and (1-oxo-1,2,3,4-tetrahydro-5 $\mathrm{H}$-2-benzocycloheptenylidene)acetic acid 11 in variable yields and (B) thermal condensation with glyoxylic acid at 160 ${ }^{\circ} \mathrm{C}$ in quantitative yields (Table 1). Subsequent reduction of the alkene acids with zinc and acetic acid gave the saturated acids $\mathbf{1 2 - 1 5}$ also in quantitative yields (Table 2). 1-Tetralone-2-acetic acid, 12, was also prepared with an overall yield of $75 \%$ by hydrolysis of the 


\section{Scheme 1}

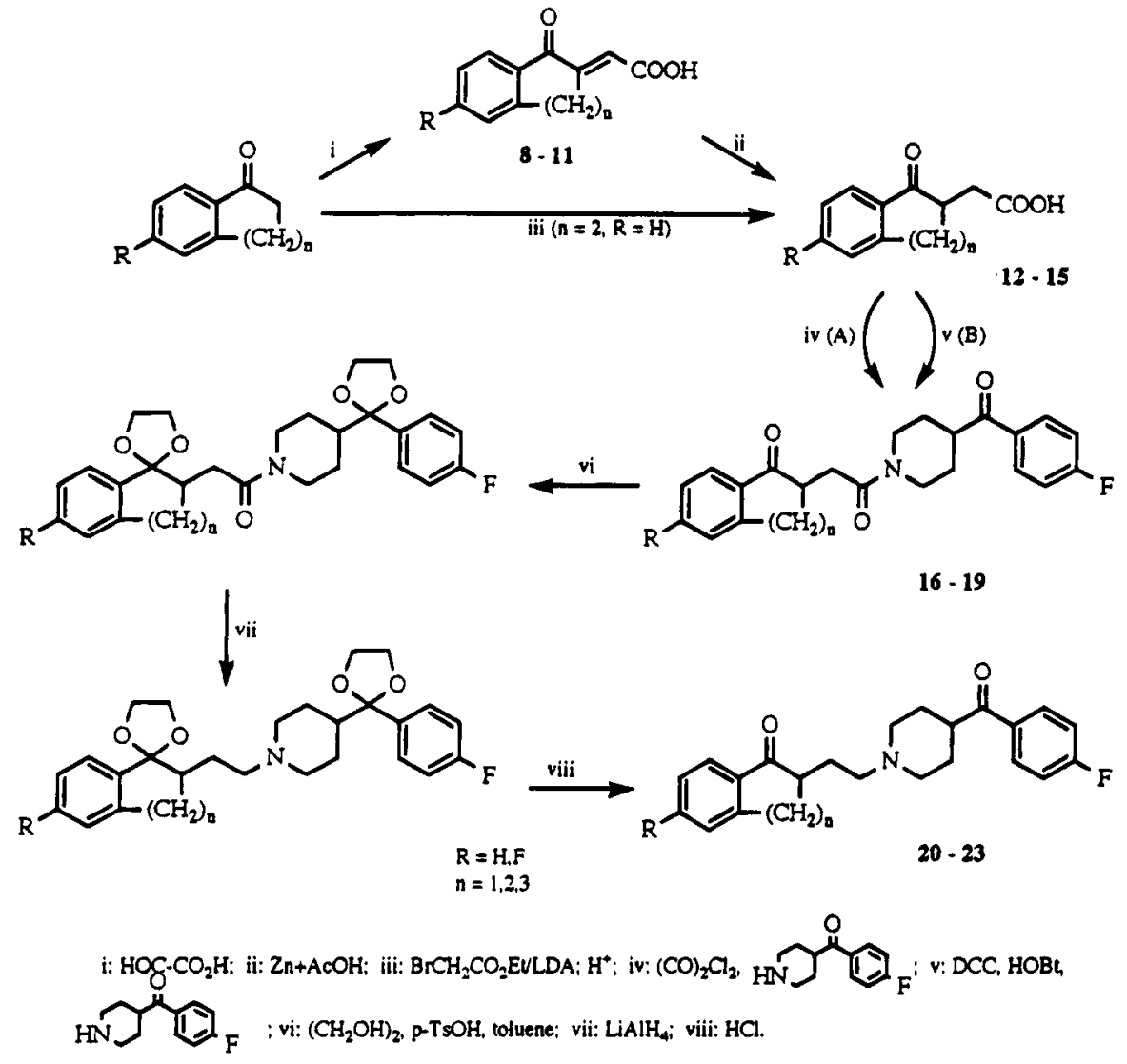

Table 1. Physical Properties for Compounds 8-11<smiles>[R]c1ccc(C(=O)/C(C)=C/C(=O)O)c(C)c1</smiles>

\begin{tabular}{|c|c|c|c|c|c|c|c|}
\hline compd & $n$ & $\mathbf{R}$ & method & $\begin{array}{c}\text { yield, } \\
\%\end{array}$ & $\mathrm{mp},{ }^{\circ} \mathrm{C}$ & $\begin{array}{l}\text { recrystn } \\
\text { solv }\end{array}$ & formula \\
\hline 8 & 1 & $\mathrm{H}$ & $\bar{A}$ & 22 & & & \\
\hline & & & B & 57 & $201-202$ & EtoH & $\mathrm{C}_{11} \mathrm{H}_{9} \mathrm{O}_{3}$ \\
\hline $\begin{array}{r}9 \\
10\end{array}$ & $\begin{array}{l}1 \\
2\end{array}$ & $\begin{array}{l}F \\
H\end{array}$ & $\begin{array}{l}\text { B } \\
\text { A }\end{array}$ & $\begin{array}{l}69 \\
74^{a}\end{array}$ & $210-212$ & EtOH & \\
\hline & & & & 95 & $188-190^{b}$ & $\mathrm{EtOH}$ & $\mathrm{C}_{12} \mathrm{H}_{10} \mathrm{O}_{3}$ \\
\hline 11 & 3 & $\mathrm{H}$ & B & 70 & $229-231^{c}$ & $\mathrm{EtOH}$ & $\mathrm{C}_{13} \mathrm{H}_{11} \mathrm{O}_{3}$ \\
\hline
\end{tabular}

${ }^{a}$ As reported in ref $20,67 \%,{ }^{b} \mathrm{mp} 184.5-185.5^{\circ} \mathrm{C} .{ }^{20} \mathrm{c} \mathrm{mp} 232$ ${ }^{\circ} \mathrm{C}(\mathrm{AcOH}){ }^{36}$

Table 2. Physical Properties for Compounds 12-15<smiles>[R]c1ccc(C(=O)C(CC(=O)O)CC(C)C)c(C)c1</smiles>

\begin{tabular}{ccccccc}
\hline compd & $n$ & $\mathrm{R}$ & yield, $\%$ & $\mathrm{mp},{ }^{\circ} \mathrm{C}$ & recrystn solv & formula \\
\hline 12 & 1 & $\mathrm{H}$ & 66 & $147-149^{a}$ & AcOEt & $\mathrm{C}_{11} \mathrm{H}_{10} \mathrm{O}_{3}$ \\
13 & 1 & $\mathrm{~F}$ & 92 & $130-133$ & toluene & $\mathrm{C}_{11} \mathrm{H}_{9} \mathrm{O}_{3} \mathrm{~F}$ \\
14 & 2 & $\mathrm{H}$ & 95 & $107-109^{b}$ & AcOEt & $\mathrm{C}_{12} \mathrm{H}_{12} \mathrm{O}_{3}$ \\
15 & 3 & $\mathrm{H}$ & 87 & $123-127$ & AcOEt & $\mathrm{C}_{13} \mathrm{H}_{14} \mathrm{O}_{3}$ \\
\hline
\end{tabular}

${ }^{a}$ Lit. $^{21} 144-146^{\circ} \mathrm{C} ;$ lit. $^{24} 147-148^{\circ} \mathrm{C}$; lit. $^{26} 147-149^{\circ} \mathrm{C}$. ${ }^{b}$ Lit. $^{23}$ $106-108^{\circ} \mathrm{C}$; lit. ${ }^{25} 104-105{ }^{\circ} \mathrm{C}$; lit. ${ }^{37} 108^{\circ} \mathrm{C}$; lit. ${ }^{38} 107-109^{\circ} \mathrm{C}$.

corresponding ethyl ester, in turn obtained by alkylation of tetralone with ethyl bromoacetate in the presence of lithium diisopropylamide. The synthesis of amides 16$\mathbf{1 9}$ (Table 3) was accomplished in good to excellent yields
Table 3. Physical Properties for Compounds 16-19<smiles>[R]c1ccc(C(=O)C(C)CC(=O)N2CCC(C(=O)c3ccc(F)cc3)CC2)c(C)c1</smiles>

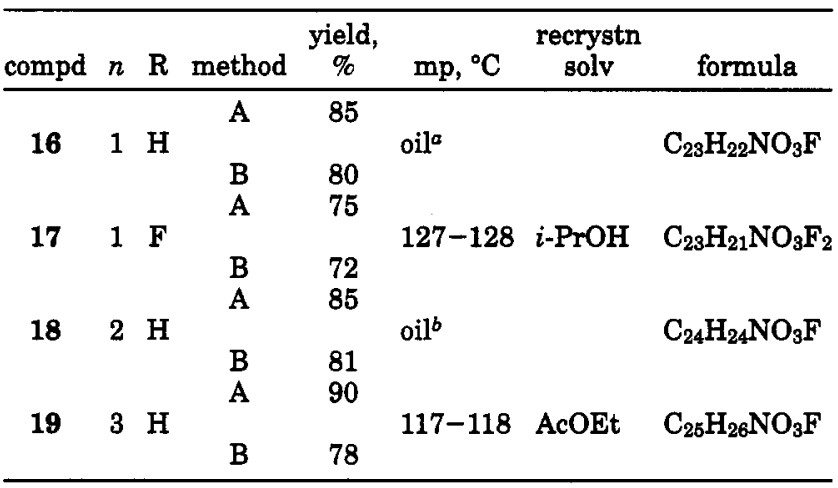

${ }^{a}$ Bis(2,4-dinitrophenyl)hydrazone, mp $180-181{ }^{\circ} \mathrm{C}(\mathrm{MeOH})$. Anal. $\left(\mathrm{C}_{35} \mathrm{H}_{30} \mathrm{~N}_{9} \mathrm{O} 9 \mathrm{~F}\right) \mathrm{C}, \mathrm{H}, \mathrm{N}$. MS (FAB) M $+1: 740 .{ }^{b} \mathrm{Bis}(2,4-$ dinitrophenyl)hydrazone, $m p \quad 207-208{ }^{\circ} \mathrm{C}$ (AcOEt). Anal. $\left(\mathrm{C}_{36} \mathrm{H}_{32} \mathrm{~N}_{9} \mathrm{O} \mathrm{g}\right) \mathrm{C}, \mathrm{H}, \mathrm{N}$. MS (FAB) $\mathrm{M}+1: 754$.

by reaction of the acid chlorides with 4-(p-fluorobenzoyl)piperidine (route $A$ ) or by direct acid amine coupling with carboxylate activation by dicyclohexylcarbodiimide in the presence of 1-hydroxybenzotriazole ( $\mathrm{HOBt}$ ) (route B). Ketalization of both the carbonyl groups with ethylene glycol and $p-\mathrm{TsOH}$ in toluene gave the bis(ethylene ketals) with variable yields. Later, lithium aluminum hydride reduction and subsequent deketalization then afforded to the amino ketones $20-23$ in good to excellents yields (Table 4). 
Table 4. Physical Properties for Compounds 20-23<smiles>[R]c1ccc(C(=O)C(C)CCN2CCC(C(=O)c3ccc(F)cc3)CC2)c(C)c1</smiles>

\begin{tabular}{|c|c|c|c|c|c|c|}
\hline $\begin{array}{c}\text { compd } \\
\text { (code number) }\end{array}$ & $n$ & $\mathrm{R}$ & yield, \% & $\mathrm{mp},{ }^{\circ} \mathrm{C}$ & recrystn solv & formula \\
\hline $\begin{array}{l}\mathbf{2 0} \\
(\mathrm{QF} 0307 \mathrm{~B})\end{array}$ & 1 & $\mathrm{H}$ & 91 & $264-266$ & $\mathrm{MeOH}$ & $\mathrm{C}_{23} \mathrm{H}_{24} \mathrm{NO}_{2} \mathrm{~F} \cdot \mathrm{HCl}$ \\
\hline $\begin{array}{l}\mathbf{2 1} \\
\text { (QF 0313B) }\end{array}$ & 1 & $\mathrm{~F}$ & 55 & $270-272$ & $\mathrm{MeOH}-\mathrm{Et}_{2} \mathrm{O}$ & $\mathrm{C}_{23} \mathrm{H}_{23} \mathrm{NO}_{2} \mathrm{~F}_{2} \cdot \mathrm{HCl}$ \\
\hline $\begin{array}{l}\mathbf{2 2} \\
\text { (QF 0303B) }\end{array}$ & 2 & $\mathrm{H}$ & 85 & $176-179$ & $\mathrm{MeOH}$ & $\mathrm{C}_{24} \mathrm{H}_{26} \mathrm{NO}_{2} \mathrm{~F} \cdot \mathrm{HCl}$ \\
\hline $\begin{array}{l}\mathbf{2 3} \\
(\mathrm{QF} \text { 0311B) }\end{array}$ & 3 & $\mathrm{H}$ & 80 & $224.5-226$ & $\mathrm{MeOH}-\mathrm{Et}_{2} \mathrm{O}$ & $\mathrm{C}_{25} \mathrm{H}_{28} \mathrm{NO}_{2} \mathrm{~F} \cdot \mathrm{HCl}$ \\
\hline
\end{tabular}

Table $5^{a}$

\begin{tabular}{|c|c|c|c|c|c|c|c|}
\hline \multirow[b]{2}{*}{ drug } & \multicolumn{3}{|c|}{$\mathrm{p} K_{\mathrm{i}}$ values } & \multicolumn{3}{|c|}{$\mathrm{p} K_{\mathrm{i}}$ ratios } & \multirow[b]{2}{*}{$\mathrm{p} A_{2} 5-\mathrm{HT}_{2 \mathrm{~A}}$} \\
\hline & $\mathrm{D}_{1}$ & $\mathrm{D}_{2}$ & $5-\mathrm{HT}_{2 \mathrm{~A}}$ & $\mathrm{D}_{1} / \mathrm{D}_{2}$ & $5-\mathrm{HT}_{2 \mathrm{~A}} / \mathrm{D}_{1}$ & $5-\mathrm{HT}_{2 \mathrm{~A}} / \mathrm{D}_{2}$ & \\
\hline haloperidol & 7.01 & 8.30 & 7.70 & 0.85 & 1.10 & 0.93 & - \\
\hline 20 & 5.55 & 7.15 & 8.60 & 0.78 & 1.55 & 1.20 & $8.12 \pm 0.4$ \\
\hline 21 & 5.96 & 7.32 & 8.42 & 0.81 & 1.41 & 1.15 & $8.12 \pm 0.7$ \\
\hline 22 & 5.81 & 7.32 & 8.11 & 0.79 & 1.40 & 1.11 & $7.45 \pm 0.2$ \\
\hline 23 & 5.89 & 7.33 & 7.89 & 0.80 & 1.34 & 1.08 & $6.75 \pm 0.1$ \\
\hline ketanserin & - & - & - & - & - & - & $8.87 \pm 0.1$ \\
\hline methysergide & - & - & 8.84 & - & - & - & - \\
\hline
\end{tabular}

${ }^{a} \mathrm{p} K_{\mathrm{i}}$ 's were obtained from the inhibition of $\left[{ }^{3} \mathrm{H}\right]$ ketanserin binding to rat frontal cortex membranes $\left(5-\mathrm{HT}_{2 \mathrm{~A}}\right)$ and $\left[{ }^{3} \mathrm{H}\right] \mathrm{spiperone}$ or $\left[{ }^{3} \mathrm{H}\right] \mathrm{SCH} 23390$ binding to striatal membranes $\left(D_{2}\right.$ or $\left.D_{1}\right)$ by new compounds. Results are means \pm SEM of three or four separate experiments. $\mathrm{D}_{1} / \mathrm{D}_{2}, \mathrm{p} K_{\mathrm{i}}$ value of $\mathrm{D}_{1}$ binding $/ \mathrm{D}_{2}$ binding; $5-\mathrm{HT}_{2 \mathrm{~A}} / \mathrm{D}_{1}, \mathrm{p} K_{\mathrm{i}}$ value of $5-\mathrm{HT}_{2 \mathrm{~A}}$ binding $/ \mathrm{D}_{1}$ binding; $5-\mathrm{HT} \mathrm{T}_{2 \mathrm{~A}} / D_{2}, \mathrm{p} K_{\mathrm{i}}$ value of $5-\mathrm{HT}_{2 \mathrm{~A}}$ binding/ $\mathrm{D}_{1}$ binding. $\mathrm{p} A_{2}$ values were obtained against serotonin-induced contractions in rat aorta rings. $(-)$ not evaluated.

\section{Results and Discussion}

Pharmacology. Dopamine and 5- $\mathrm{HT}_{2 \mathrm{~A}}$ antagonist activity of the compounds was evaluated by in vivo and in vitro experiments.

In Vitro Results. In $\left[{ }^{3} \mathrm{H}\right]$ spiperone binding assays, all the new compounds exhibited $\mathrm{p} K_{\mathrm{i}}$ values of $7.15-$ 7.33, slightly lower than that of haloperidol, 8.3 (Table 5). In $\left[{ }^{3} \mathrm{H}\right] \mathrm{SCH} 23390$ binding assays, the new molecules again had very similar $\mathrm{p} K_{\mathrm{i}}$ values $(5.55-5.96)$ which were again lower than that of haloperidol (7.01). These results indicate that the new compounds are more $D_{2}$ selective than haloperidol.

In $\left[{ }^{3} \mathrm{H}\right]$ ketanserin binding experiments, the new molecules showed greater affinity for $5-\mathrm{HT}_{2 \mathrm{~A}}$ receptors $\left(\mathrm{p} K_{\mathrm{i}}\right.$ $7.89-8.60)$ than haloperidol $\left(\mathrm{p} K_{\mathrm{i}} 7.70\right)$. The new compounds exhibited $\mathrm{p} A_{2}$ values of $6.75-8.12,{ }^{27}$ slightly lower than that of ketanserin (8.87) in suppressing serotonin-induced contractions in rat aorta rings stripped of endothelium (Table 5).

$\mathrm{p} K_{\mathrm{i}}$ 's for $\mathrm{D}_{2}$ binding (and to a lesser extent $\mathrm{p} K_{\mathrm{i}}$ 's for $\mathrm{D}_{1}$ binding) tend to be greater among typical (classical) than atypical antipsychotics, whereas these two classes of antipsychotic exhibit no difference as regards $\mathrm{p} K_{\mathrm{i}}$ 's for $5-\mathrm{HT}_{2 \mathrm{~A}}$ binding. 28,29

In Vivo Results. All the substances tested caused statistical significant reductions in spontaneous motor activity (SMA) at a dose of $2 \mathrm{mg} / \mathrm{kg}$ (Figure 3). Haloperidol and compounds 20,23 , and 21 were effective immediately after their administration, and 22, $40 \mathrm{~min}$ later.

Depending on the reductions of SMA obtained with 2 $\mathrm{mg} / \mathrm{kg}$ doses, the substances were next assayed at doses 4 times greater or smaller. The percent reduction in SMA measured $60 \mathrm{~min}$ after administration of $8 \mathrm{mg} / \mathrm{kg}$

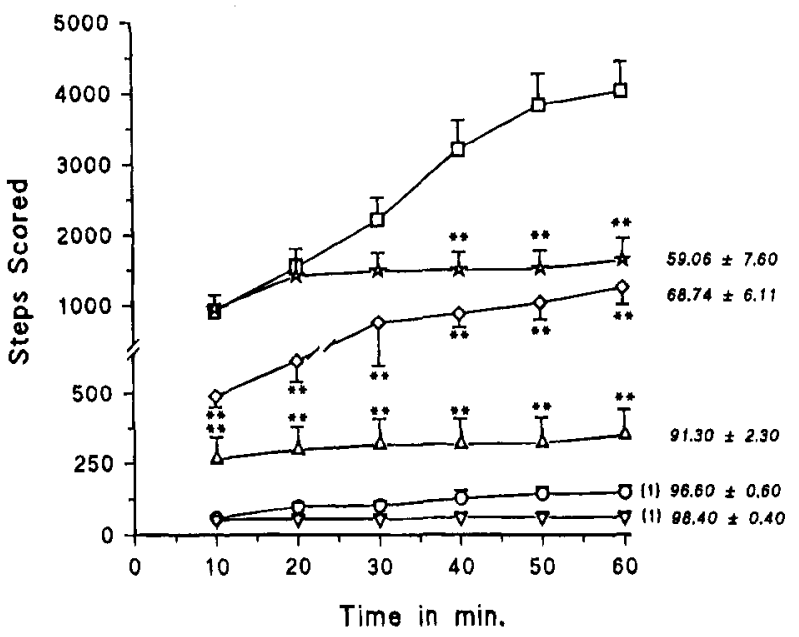

Figure 3. Spontaneous locomotor activity in mice treated with vehicle $(\square)$, haloperidol $(O), 20(\diamond), 21(\nabla), 22(\diamond)$, or $23(\Delta)$ at a dose of $2 \mathrm{mg} / \mathrm{kg}$. The data shown are means \pm SEM (accumulated data). Significant differences with respect to control indicated by ${ }^{*} p<0.05$ or ${ }^{* *} p<0.01$. (1) All values showed significant differences with respect to control $(\mathrm{p}<$ 0.01 ). Numerical values at the end of each curve show percent reduction in SMA $60 \mathrm{~min}$ after administration of the drugs.

of compound 20 or $0.5 \mathrm{mg} / \mathrm{kg}$ of 23 or 21 was in all three cases very similar to that caused by $0.5 \mathrm{mg} / \mathrm{kg}$ of haloperidol, and $22(8 \mathrm{mg} / \mathrm{kg})$ was slightly less active (Figure 4).

The new compounds were also tested for activity against amphetamine-induced hyperactivity at doses which had caused at least $75 \%$ inhibition of SMA $60 \mathrm{~min}$ after their administration. Haloperidol $\left(\mathrm{ED}_{50}=0.098\right.$ $\mathrm{mg} / \mathrm{kg}$ ip) or compound 21 at dosages of $0.5 \mathrm{mg} / \mathrm{kg}, 23$ at 0.5 or $2 \mathrm{mg} / \mathrm{kg}$, and 20 or 22 at $8 \mathrm{mg} / \mathrm{kg}$ all inhibited 


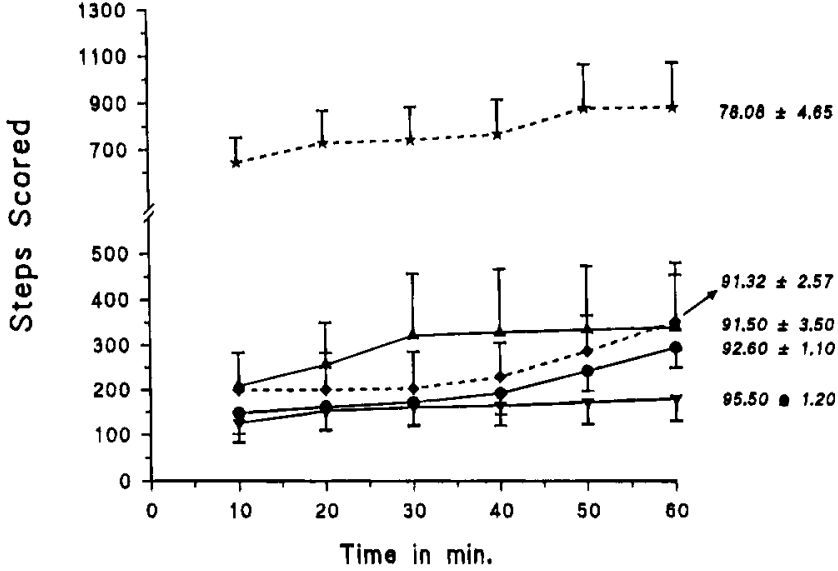

Figure 4. Spontaneous locomotor activity in mice treated with haloperidol ( ), $21(\nabla)$, or $23(\Delta)$ at a dose of $0.5 \mathrm{mg} / \mathrm{kg}$, or 20 ( ) or 22 ( at a dose of $8 \mathrm{mg} / \mathrm{kg}$. The data shown are means \pm SEM (accumulated data). All values showed significant differences with respect to control $(p<0.01)$. Numerical values at the end of each curve show percent reduction in SMA 60 min after administration of the drugs.

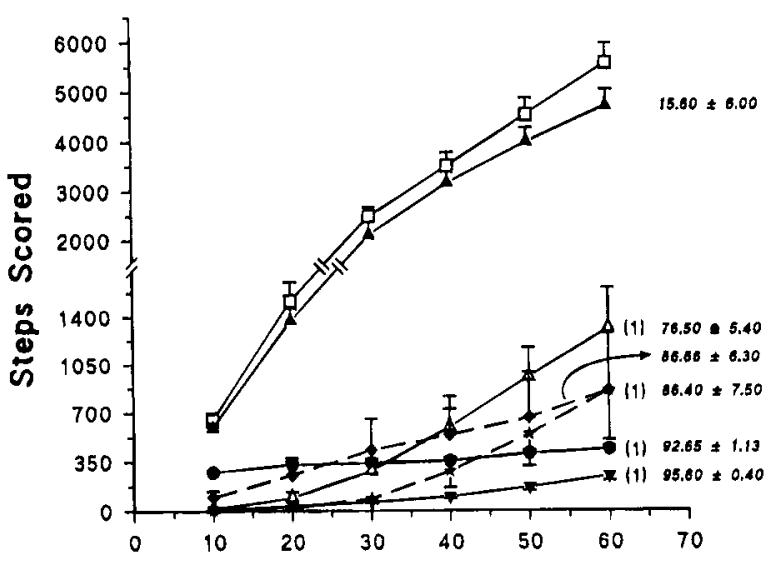

Time in min.

Figure 5. Antagonism of $d$-amphetamine-induced hypermotility in mice treated with vehicle $(\square)$, haloperidol $(\mathbf{0})$, or $\mathbf{2 1}$ $(\nabla)$ at a dose of $0.5 \mathrm{mg} / \mathrm{kg}, 23$ at doses of $0.5(\Delta)$ or $2 \mathrm{mg} / \mathrm{kg}$ $(\Delta)$, or $20(\Delta)$ or $22(s)$ at a dose of $8 \mathrm{mg} / \mathrm{kg}$. All values are means \pm SEM $(1)$ Significant differences $(p<0.01)$ with respect to control throughout the experiment. Numerical values at the end of each curve show the percent reduction in hyperactivity $60 \mathrm{~min}$ after administration of the drugs.

amphetamine-induced hyperactivity throughout the experiment (Figure 5).

Apomorphine-induced climbing was strongly inhibited by haloperidol $\left(E D_{50}=0.15 \mathrm{mg} / \mathrm{kg}\right.$ ip) and by all the new compounds at the highest dose used (Figure 6). If it is assumed, following Ferris et al., ${ }^{30}$ that climbing is caused by activation of limbic dopamine receptors, and since antipsychotic activity is the result of blockade of DA receptors in the limbic system, then these results suggest that the compounds tested can be classified as antipsychotics.

The potency of the compounds under study to inhibit spontaneous locomotor activity, amphetamine-induced hyperactivity, and apomorphine induced climbing (at the highest dose used) was similar. Thus, the indanone derivative 21 was the most potent in reducing all behaviors, followed by the benzosuberone 23 , being the least potent $\mathbf{2 0}$, analogue of $\mathbf{2 1}$, but lacking a fluorine atom in position 5 , and $\mathbf{2 2}$, bearing a tetralone moiety.
Differences in the affinity for either $D_{1}$ or $D_{2}$ receptors cannot account for the relative potencies of the compounds, since their $K_{i}$ 's were almost identical. It appears that the existence of two complete butyrophenone groups, such as in 21, is necessary to show a similar profile to haloperidol in behavioral tests.

Certain experimental results suggest that $D_{2}$ selectivity may be a sign that a drug will induce catalepsy in experimental animals (and hence that it may cause extrapyramidal symptoms in human beings). ${ }^{31,32}$ Since our binding results showed that all the new substances are more $\mathrm{D}_{2}$ selective than haloperidol, we hypothesized that they would be more cataleptogenic than haloperidol in vivo. Somewhat to our surprise, this was not so. Whereas haloperidol, as expected, was markedly cataleptogenic $\left(\mathrm{ED}_{50}=0.67 \mathrm{mg} / \mathrm{kg}\right.$ ip, confidence limits $0.5-$ $0.9)$ and induced an average increase in position retention time of $28.8 \mathrm{~s}(p<0.01)$ when the larger dose was used, the new compounds, in general, exhibited a much lower propensity to produce catalepsy. Compounds $\mathbf{2 0}$ and 22 produced, at dosages of $2-8 \mathrm{mg} / \mathrm{kg}$, a slight increase (no more than $5 \mathrm{~s}$ ) in the time for which the imposed position was maintained and induced no catalepsy, while the molecules 21 and 23 (dosages of $0.5-8$ $\mathrm{mg} / \mathrm{kg}$ ) increased the time in initial imposed posture (in the range $10-20 \mathrm{~s}$ ) and catalepsy was induced in only $13.3-33.3 \%$ and $6.7-16.7 \%$ of the tested animals, respectively; however, these percentages are much lower than those obtained with haloperidol (Figure 7). Furthermore, the effects of $\mathbf{2 1}$ and $\mathbf{2 3}$ in the catalepsy test differed qualitatively from those of haloperidol: whereas animals treated with the new molecules showed reduced muscle tone (appeared flaccid), the animals treated with haloperidol appeared rigid with high level of muscle tone.

Bruhwyler et al. ${ }^{33}$ suggested that the induction of extrapyramidal symptoms by neuroleptics may be due to an imbalance between their effects on dopaminergic and cholinergic systems, and that atypical antipsychotics, such as clozapine, may lack extrapyramidal effects because they have both antidopaminergic and anticholinergic activity. To determine whether the weak cataleptogenic activity exhibited by our new compounds might be due to anticholinergic activity, we evaluated the protection they afforded against eserine (physostigmine)-induced lethality. Since none of the new compounds afforded such protection, even at the highest dose used (results not shown), their weak cataleptogenic activity cannot, in fact, be attributed to concomitant anticholinergic activity.

Recent studies have suggested that $5-\mathrm{HT}_{2 \mathrm{~A}}$-blocking activity can reduce the cataleptogenic activity of neuroleptics while enhancing their antipsychotic activity. 3,15,34 Setoperone and ritanserin, for example, both of which are more active as 5-H'T $\mathrm{T}_{2 \mathrm{~A}}$ blockers than as $\mathrm{D}_{2}$ blockers, have been reported to be more effective than selective DA receptors blockers in reducing the negative symptoms of schizophrenia and induce few extrapyramidal side effects. In view of such reports, other compounds with both 5-HT $\mathrm{T}_{2 \mathrm{~A}}$-blocking and $\mathrm{D}_{2}$-blocking activity have also been developed. ${ }^{35}$

According to the binding studies the new compounds interacted with both $D_{1}$ and $D_{2}$ receptors like haloperidol, although they had less affinity. However, they were slightly more $\mathrm{D}_{2}$ selective compared to haloperidol, as 


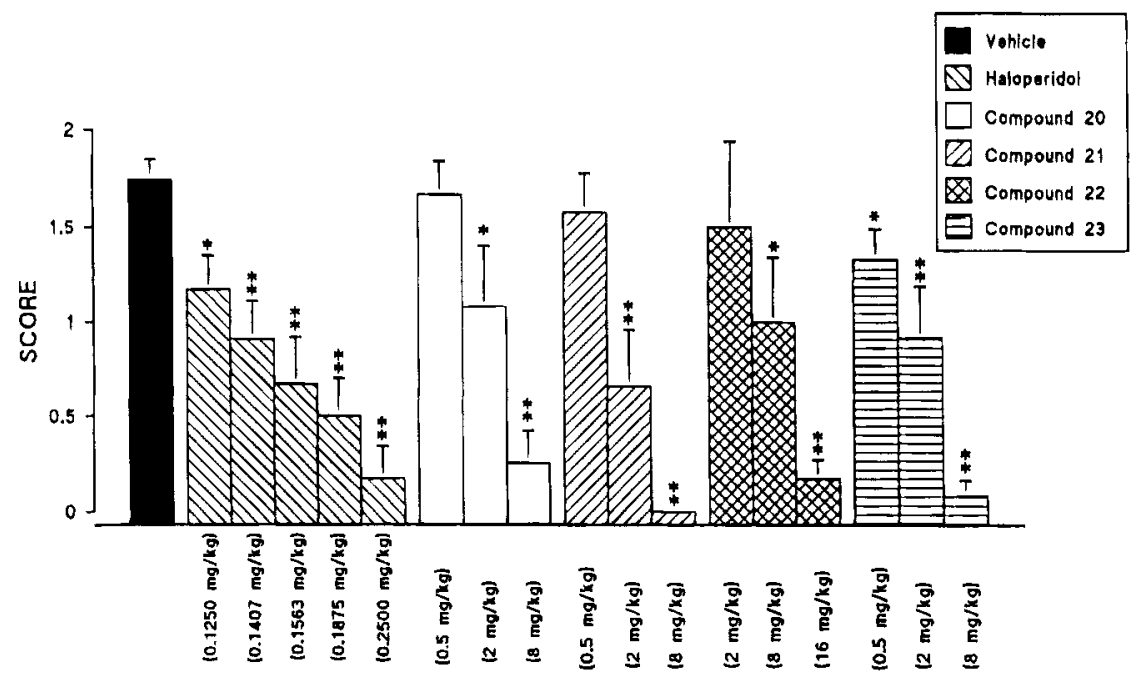

Figure 6. Climbing behavior induced by administration of apomorphine $(2 \mathrm{mg} / \mathrm{kg} \mathrm{sc}) 30 \mathrm{~min}$ after administration of vehicle, haloperidol, 20, 21, 22, or 23. All values show means \pm SEM of the scores obtained between 20-30 min postapormorphine administration. Significant differences with respect to control indicated by $* p<0.05$ or $* *<<0.01$.

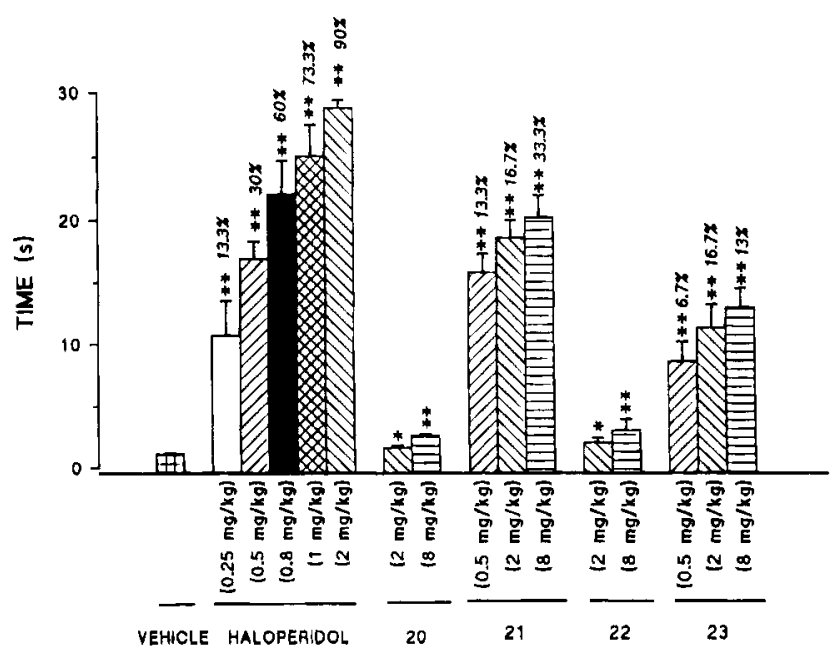

Figure 7. Results of catalepsy test, showing the time for which initial posture was maintained (mean \pm SEM) by mice treated with vehicle, haloperidol, $\mathbf{2 0}, \mathbf{2 1}, \mathbf{2 2}$, or $\mathbf{2 3}$. Times in excess of $30 \mathrm{~s}$ were recorded as $30 \mathrm{~s}$. Significant differences with respect to control indicated by ${ }^{*} p<0.05$ or ${ }^{* *} p<0.01$. Numerical values at column heads represent the percentage of cataleptics.

shown by the $D_{1} / D_{2}$ ratio. In contrast, all the new molecules displayed higher affinity for $5-\mathrm{HT}_{2 \mathrm{~A}}$ receptors than haloperidol. Interestingly, in this case the relative affinity for serotonin receptors appears to be related to the chemical structure of the compounds. 21 and 20 , both bearing an indanone moiety, but the latter lacking the fluorine atom, showed the highest affinity for $5-\mathrm{HT}_{2 \mathrm{~A}}$; the compound having a tetralone fragment (22) exhibited an affinity slightly lower, while $\mathbf{2 3}$ with the least affinity bore a benzosuberone. In summary, increasing the size of the ring which bears the carbonyl group diminishes the affinity for serotonin receptors.

In keeping with the above hypotheses regarding the combination of 5 - $\mathrm{HT}_{2 \mathrm{~A}}$-blocking and $\mathrm{D}_{2}$-blocking activities, Meltzer et al. ${ }^{28,29}$ suggested that atypical antipsychotic drugs might be characterized by having a $\mathrm{p} K_{\mathrm{i}}$ $5-\mathrm{HT}_{2 \mathrm{~A}} / \mathrm{D}_{2}$ ratio no smaller than 1.12 . The $\mathrm{p} K_{\mathrm{i}} 5-\mathrm{HT}_{2 \mathrm{~A}}$ $\mathrm{D}_{1}$ and $\mathrm{p} K_{\mathrm{i}} 5-\mathrm{HT}_{2 \mathrm{~A}} / \mathrm{D}_{2}$ ratios of our new compounds were all greater than those of haloperidol; only 20 (hereafter designed as QF 0307B) and 21 (QF 0313B) have $\mathrm{p} K_{\mathrm{i}}$ $5-\mathrm{HT}_{2 \mathrm{~A}} / \mathrm{D}_{2}$ ratios strictly higher than 1.12 , while 22<smiles>CCCC1CC2C=CC=CC2C1=O</smiles><smiles>CCCC1CCc2ccccc2C1=O</smiles><smiles>CCCC1CCCC2C=CC=CC2C1=O</smiles><smiles>O=C(C1=CCC(I)C=C1)C1CCCCC1</smiles><smiles>CCCCC(=O)c1ccccc1</smiles>

$\mathbf{Y}$

Figure 8. Molecular fragments considered in the molecular modeling analysis.

( $Q F$ 0303B) may be considered as a borderline case (Table 5). Our results with QF 0303B, QF 0307B, and QF 0311B are in accordance with Meltzer et al. In addition, QF 0313B having an appropriate $\mathrm{p} K_{\mathrm{i}} 5-\mathrm{HT}_{2 \mathrm{~N}}$ $\mathrm{D}_{2}$ ratio induced weak catalepsy in a small percentage of animals.

In summary, these new synthetic molecules had pharmacological properties compatible with a profile of atypical antipsychotics.

Molecular Modeling. Structures of the compounds $(\mathbf{2 0}, \mathbf{2 2}, \mathbf{2 3})$ were represented as $X-Y$ (Figure 8) where $\mathrm{Xs}$ are the fused cyclic moieties (indanone, tetralone, and benzosuberone; $X_{1}, X_{2}$ and $X_{3}$ in Figure 8 ) and $Y$ is the 4-( $p$-fluorobenzoyl)piperidine fragment common to all the compounds.

Structural fittings of $\mathrm{X}$ and $\mathrm{Y}$ fragments and the butyrophenone pharmacophore of haloperidol were performed by starting from their most stable conformations, superimposing the carbonyl groups, effecting torsions bringing the terminal nitrogen as close as possible to this of the template molecule, and then optimizing with these contraints. All the torsions affected only linear aliphatic chains and involved very little change in energy.

Fitting the butyrophenone pharmacophore of haloperidol to $\mathrm{Y}$ as above resulted in almost perfect overlap, with $\mathrm{N}$ atoms at only $0.09 \AA$ (Figure 9). Since both structures block dopamine receptors (see Pharmacology section), this suggests that the active conformation of haloperidol fragment may not be its minimum-energy conformation (Figure 9a) but a more twisted for closer to $\mathrm{Y}$ (Figure $9 \mathrm{~b}$ ). In this specific case, the energetic cost to acquire this final conformation is only $0.85 \mathrm{kcal} / \mathrm{mol}$; that it to say, nearly a free rotation. 


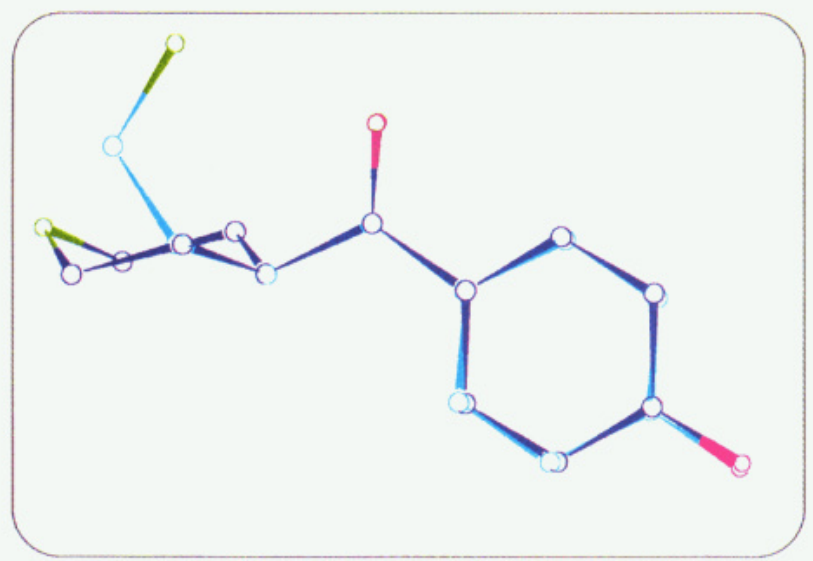

(A)

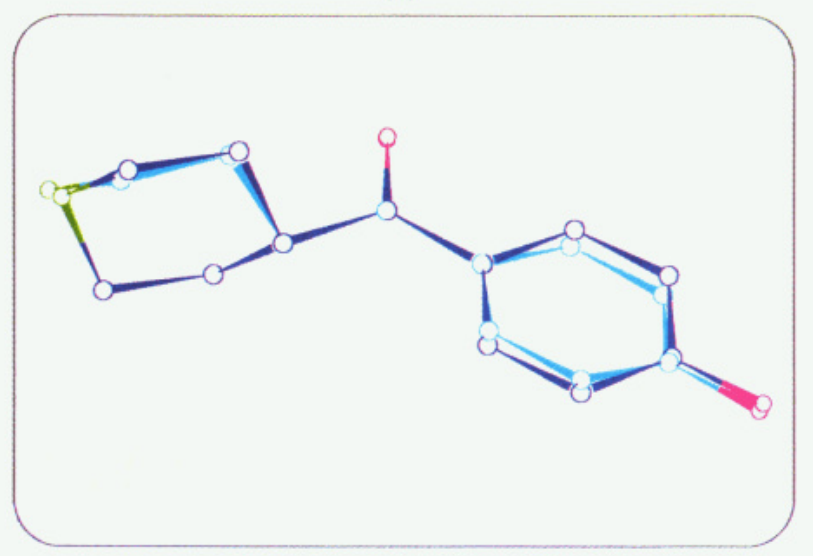

(B)

C-C $\quad$ C $-\mathrm{C}-\mathrm{C}-\mathrm{P}$

Figure 9. Structural fitting of the haloperidol pharmacophore on the 4-( $p$-fluorobenzoyl)piperidine fragment (Y). (a) Both molecules in minimum-energy conformation. (b) Haloperidol pharmacophore twisted to match fragment Y.

Following the same previously described procedure, the rigid 4-( $p$-fluorobenzoyl)piperidine fragment $(\mathrm{Y})$ was used as a template to which the three $\mathrm{X}$ fragments were fitted (Figure 10). Since the goodness of the fit was unaffected by the size of the rings, and since all the $\mathrm{X}$ fragments appear to be pharmacologically effective, planarity of the aryl systems related to their size seems not to influence the dopamine-blocking activity of these structures. This finding contrasts with those of a parallel study of their 5 - $\mathrm{HT}_{2 \mathrm{~A}}$-blocking activity. ${ }^{27}$

\section{Experimental Section}

Chemistry. Melting points were determined with a Kofler hot-stage instrument or a Gallenkamp capillary melting points and are uncorrected. Infrared spectra were recorded with a Perkin-Elmer 1600 FTIR spectrophotometer; main bands are given in $\mathrm{cm}^{-1}$. Proton magnetic resonance spectra were obtained with a Brucker WM-250 $(250 \mathrm{MHz})$ with tetramethylsilane as an internal standard. Mass spectra (FAB) were performed with a Kratos MS-50 mass spectrometer using 2-hydroxyethyl disulfide as a matrix. Elemental analyses were performed in a Perkin-Elmer 240B apparatus at the Microanalyses Service of the University of Santiago de Compostela (Spain); all reported values are within $\pm 0.4 \%$ of the theoretical compositions.

The general method of synthesis described are illustrative of those analogous compounds.

The progress of the reactions was monitored by the thinlayer chromatography.

1-Oxo-1,2,3,4-tetrahydro-2-naphthylideneacetic Acid (10) (Table 1). Method B. A stirred mixture of $2.2 \mathrm{~g}$ (15

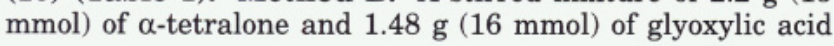

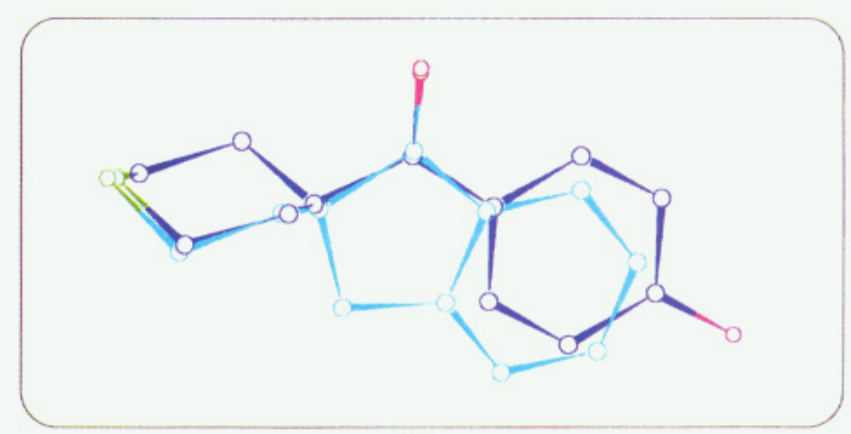

(A)

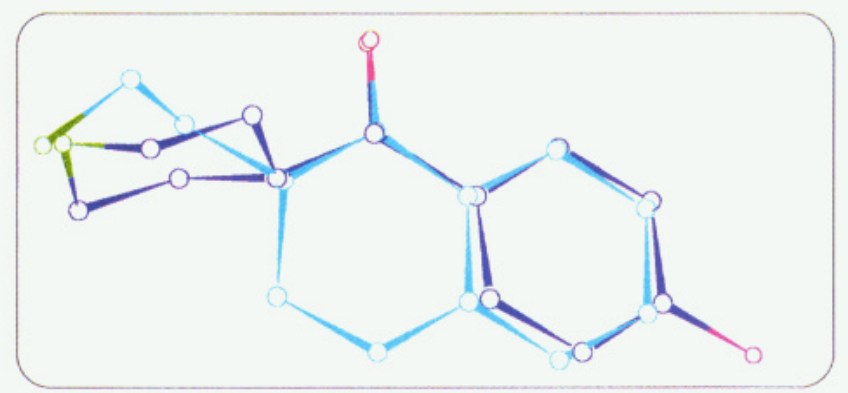

(B)

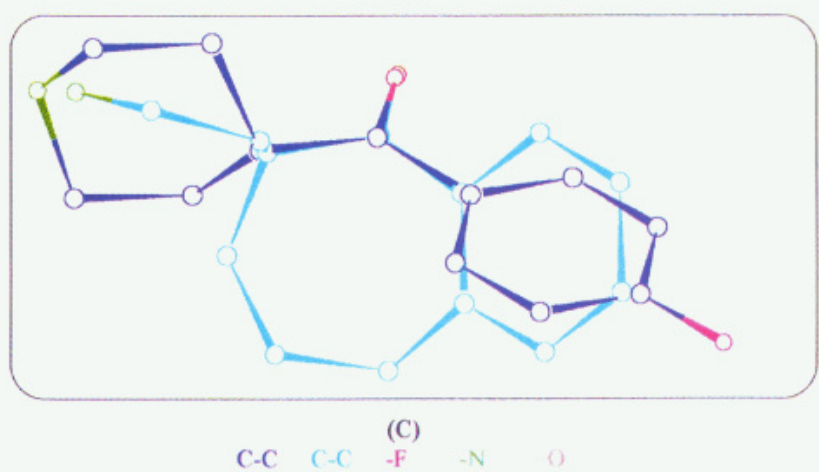

Figure 10. Structural fitting of $\mathrm{X}$ fragments on the 4-( $p$ fluorobenzoyl)piperidine fragment (Y) taken as template. (a) Indanone $\left(\mathrm{X}_{1}\right)$; (b) tetralone $\left(\mathrm{X}_{2}\right)$; and (c) benzosuberone $\left(\mathrm{X}_{3}\right)$.

monohydrate was heated in a Dean-Stark apparatus at 160 ${ }^{\circ} \mathrm{C}$ for 40-45 min. After cooling, the solid which formed was thoroughly triturated with ethyl acetate $(2 \times 50 \mathrm{~mL})$. After filtration to separate undissolved materials, the liquid filtrate was washed several times with water and dried $\left(\mathrm{Na}_{2} \mathrm{SO}_{4}\right)$, and the solvent was evaporated to give $2.90 \mathrm{~g}(95 \%)$ of 10 . A sample for analysis was obtained by recrystallization from EtOH. Mp: $188-190^{\circ} \mathrm{C}$. IR (KBr): $3400-2500(\mathrm{OH}), 1700$ $(\mathrm{COOH}), 1670(\mathrm{CO}), 1640-1600(\mathrm{C}=\mathrm{C}) .{ }^{1} \mathrm{H}$ NMR $\left(\mathrm{CDCl}_{3}\right): \delta$ $8.11-8.08$ (d, $1 \mathrm{H}, \mathrm{H}-8), 7.63-7.57$ (dt, $1 \mathrm{H}, \mathrm{H}-6), 7.44-7.38$ (t, $1 \mathrm{H}, \mathrm{H}-7$ ), $7.35-7.31$ (d, 1H, H-5) $6.92(\mathrm{~s}, 1 \mathrm{H},=\mathrm{CHCOO}), 3.48-$ $3.42\left(\mathrm{~m}, 2 \mathrm{H}, \mathrm{PhCH}_{2}\right), 3.17-3.00\left(\mathrm{~m}, 2 \mathrm{H}, \mathrm{PhCH}_{2} \mathrm{CH}_{2}\right)$.

1-Oxo-1,2,3,4-tetrahydro-2-naphthaleneacetic Acid (14) (Table 2). 14 was prepared by reduction of 10 with zinc dust and acetic acid as previously described. ${ }^{38} \mathrm{Mp}$ : $107-109{ }^{\circ} \mathrm{C}$.

The acetic acid 14 was also prepared by hydrolysis of the corresponding ethyl ester as indicated below.

A solution of $1.06 \mathrm{~mL}$ ( $7.5 \mathrm{mmol})$ of diisopropylamine in 40 $\mathrm{mL}$ of dried THF was cooled to $-20^{\circ} \mathrm{C}$ under $\mathrm{N}_{2}$ with stirring. $n$-Butyllithium (3.06 mL of a $2.5 \mathrm{M}$ solution in $n-\mathrm{C}_{6} \mathrm{H}_{14} ; 7.5$ $\mathrm{mmol}$ ) was added, and stirring was continued for $0.5 \mathrm{~h}$ between -20 and $-10^{\circ} \mathrm{C}$. The solution was then cooled to $-70^{\circ} \mathrm{C}$ and stirred $1 \mathrm{~h}$ more. A solution of $1.10 \mathrm{~g}(7.5 \mathrm{mmol})$ of $\alpha$-tetralone in $8 \mathrm{~mL}$ of THF was added dropwise over 5-10 min. After 15 min at $-70^{\circ} \mathrm{C}$ the cooling bath was removed and the reaction mixture was allowed to warm to room temperature under $\mathrm{N}_{2}$ over $18 \mathrm{~h}$. The THF was evaporated off, and the residue was dissolved in AcOEt $/ \mathrm{H}_{2} \mathrm{O}$. The solution was washed with $5 \%$ $\mathrm{NaHCO}_{3}$ and $5 \% \mathrm{HCl}$ and dried $\left(\mathrm{Na}_{2} \mathrm{SO}_{4}\right)$, and the AcOEt was evaporated off to give $1.71 \mathrm{~g}$ of crude product, which was purified by chromatography on silica gel with $\mathrm{CH}_{2} \mathrm{Cl}_{2}$ as eluent, 
yielding $1.34 \mathrm{~g}$ (77\%) of the desired 1-oxo-1,2,3,4-tetrahydro2-naphthaleneacetic acid, ethyl ester. Mp: $47-49{ }^{\circ} \mathrm{C}$. IR (KBr): 1730 (COO), 1682 (CO), $1600(\mathrm{C}=\mathrm{C}) .{ }^{1} \mathrm{H}-\mathrm{NMR}$ $\left(\mathrm{CDCl}_{3}\right): \delta 8.04-8.01$ (dd, $\left.1 \mathrm{H}, \mathrm{H}-8\right), 7.50-7.44$ (dt, $\left.1 \mathrm{H}, \mathrm{H}-6\right)$, $7.33-7.23(\mathrm{~m}, 2 \mathrm{H}, \mathrm{H}-5, \mathrm{H}-7), 4.23-4.12\left(\mathrm{~m}, 2 \mathrm{H}, \mathrm{COOCH}_{2} \mathrm{CH}_{3}\right)$, 3.20-2.92 (cm, 4H, $\left.\mathrm{CH}_{2} \mathrm{AR}, \mathrm{CH}_{2} \mathrm{COO}\right), 2.47-2.35(\mathrm{~m}, 1 \mathrm{H}, 2 \mathrm{H}$, $\mathrm{H}-5, \mathrm{H}-7,=\mathrm{CH}), 2.30-1.88(\mathrm{~m}, 2 \mathrm{H}, \mathrm{HCHCH}=), 1.31-1.22(\mathrm{dt}$, $3 \mathrm{H}, \mathrm{CH}_{3}$ ).

Acid hydrolysis of this ethyl ester with concentrated $\mathrm{HCl}$ gave 14 in quantitative yield. $\mathrm{Mp}: 107-109^{\circ} \mathrm{C}(\mathrm{EtOH})$. IR $(\mathrm{KBr}): 3100-2500(\mathrm{OH}), 1710(\mathrm{COOH}), 1680(\mathrm{CO})$ (see Table 2).

1-Oxo-1,2,3,4-tetrahydro-2-naphthaleneacetic Acid Chloride. A solution of $76.2 \mathrm{~g}(0.6 \mathrm{~mol})$ of oxalyl chloride in $40 \mathrm{~mL}$ of anhydrous toluene was added dropwise to a stirred solution of $12.02 \mathrm{~g}(0.06 \mathrm{mmol})$ of 13 in $260 \mathrm{~mL}$ of anhydrous toluene under an atmosphere. The resulting reaction mixture was allowed to stir overnight at room temperature. The solvent was removed under reduced pressure, and the orange solid residue was used in the next step without further purification. IR: strong band at $1794 \mathrm{~cm}^{-1}(\mathrm{O}=\mathrm{CCl})$. Quantitative yield.

$N$-[(1-Oxo-1,2,3,4-tetrahydro-2-naphthyl)acetyl]-4-(pfluorobenzoyl)piperidine (18), Route A. A solution of 1.91 $\mathrm{g}(22 \mathrm{mmol})$ of ( $p$-fluorobenzoyl)piperidine in $30 \mathrm{~mL}$ of anhydrous toluene was slowly added to a stirred solution of $1.97 \mathrm{~g}$ $(8.9 \mathrm{mmol})$ of acid chloride in $130 \mathrm{~mL}$ of anhydrous toluene under argon atmosphere. The resutling mixture was allowed to stir for $1 \mathrm{~h}$ and then heated under reflux for $24 \mathrm{~h}$. After cooling, the solvent was removed under reduced pressure to give a brown oil which was dissolved in dichloromethane, the resulting solution washed with $10 \% \mathrm{Na}_{2} \mathrm{CO}_{3}$ and $\mathrm{H}_{2} \mathrm{O}$ and dried $\left(\mathrm{Na}_{2} \mathrm{SO}_{4}\right)$, and the solvent was removed in vacuo. The resulting orange oil was purifed by flash chromatography (silica gel, AcOEt/hexane, 1:1) to give $1.1 \mathrm{~g}(95 \%)$ of a yellow oil that does not crystallize on standing. Attempted Kugelrohr distillation caused decomposition. IR (film): 1715 (CO cycloalkanone), 1678 (CO benzoyl), $1643(\mathrm{CO}-\mathrm{N})$. The bis $(2,4-$ dinitrophenyl)hydrazone melted at $207-208^{\circ} \mathrm{C}$ (AcOEt) (see Table 3).

Route B. Under an argon atmosphere, a solution of $0.61 \mathrm{~g}$ $(2.94 \mathrm{mmol})$ of 4 -( $p$-fluorobenzoyl)piperidine, $N$-hydroxybenzotriazole $(0.80 \mathrm{~g}, 5.88 \mathrm{mmol})$, and $0.60 \mathrm{~g}(2.94 \mathrm{mmol})$ of the acid 14 was stirred at room temperature for $1 \mathrm{~h} ; 1.21 \mathrm{~g}(5.88$ mmol) of $N, N$-dicyclohexylcarbodiimide was then added to the cooled mixture $\left(0^{\circ} \mathrm{C}\right)$ which was stirred at $0^{\circ} \mathrm{C}$ for $1 \mathrm{~h}$ and then for $16 \mathrm{~h}$ at room temperature. After removal of the DMF in vacuo, the residue obtained was dissolved in $\mathrm{CH}_{2} \mathrm{Cl}_{2}(150$ $\mathrm{mL}$ ), and the resulting solution was washed with $5 \% \mathrm{NaHCO}_{3}$ $(2 \times 25 \mathrm{~mL})$ and $\mathrm{H}_{2} \mathrm{O}(2 \times 40 \mathrm{~mL})$ and dried $\left(\mathrm{Na}_{2} \mathrm{SO}_{4}\right)$, and the solvent was removed under reduced pressure. The oil residue was purified by flash chromatography (silica gel, AcOEt/hexane $1: 1$ ) to give $0.94 \mathrm{~g}(81 \%)$ of a yellow oil that was identified by IR and as 2,4-dinitrophenylhydrazone, mp 207$208^{\circ} \mathrm{C}$ (EtOH) (see Table 3 ).

$N$-[ $\beta$-(1-Oxo-1,2,3,4-tetrahydro-2-naphthyl)ethyl]-4-( $p$ fluorobenzoyl)piperidine Bis(ethylene ketal). A stirred solution of $1.76 \mathrm{~g}(46 \mathrm{mmol})$ of the amide $18,17.27 \mathrm{~g}(0.28$ mmol) of ethylene glycol, and $54 \mathrm{mg}$ of $p-\mathrm{TsOH}_{\mathrm{s}}$ in $55 \mathrm{~mL}$ of anhydrous toluene was refluxed in a Dean-Stark apparatus for $22.5 \mathrm{~h}$ with azeotropic distillation of water. After cooling, the toluene solution was washed with $10 \% \mathrm{Na}_{2} \mathrm{CO}_{3}(2 \times 30$ $\mathrm{mL})$ and $\mathrm{H}_{2} \mathrm{O}(2 \times 30 \mathrm{~mL})$ and dried $\left(\mathrm{Na}_{2} \mathrm{SO}_{4}\right)$, and the solvent was removed under reduced pressure. The resulting crude bisketal $(2.05 \mathrm{~g}, 95 \%)$ was an orange oil with only one IR band $(1650, \mathrm{CO}-\mathrm{N})$ and was used in the next step without further purification.

$N$ - $[\beta$-(1-Oxo-1,2,3,4-tetrahydro-2-naphthyl)ethyl $]-4-(p-$ fluorobenzoyl)piperidine (22). A solution of $0.83 \mathrm{~g}(0.003$ $\mathrm{mol}$ ) of 18 bis(ethylene ketal) in $25 \mathrm{~mL}$ of ether was added dropwise to a stirred suspension of $0.47 \mathrm{~g}(0.012 \mathrm{~mol})$ of $\mathrm{LiAlH}_{4}$ in $16 \mathrm{~mL}$ of anhydrous ether under an argon atmosphere. The reaction mixture was heated under reflux for $8 \mathrm{~h}$, cooled at 0 ${ }^{\circ} \mathrm{C}$ in an ice bath, and quenched by the sequential dropwise addition of $\mathrm{H}_{2} \mathrm{O}(0.5 \mathrm{~mL}), 10 \% \mathrm{NaOH}(0.7 \mathrm{~mL})$, and $\mathrm{H}_{2} \mathrm{O}(3$ $\mathrm{mL}$ ). The coarse precipitate formed was filtered off and thoroughly washed with ether. The combined filtrates were treated with $10 \% \mathrm{HCl}$ and stirred vigorously at $35-40^{\circ} \mathrm{C}$ for $1 \mathrm{~h}$. On cooling, the aqueous layer was made alkaline with $10 \% \mathrm{NaOH}$ and extracted with ether $(3 \times 50 \mathrm{~mL})$, the combined ether extracts were dried $\left(\mathrm{Na}_{2} \mathrm{SO}_{4}\right)$, and the solvent was partially removed under reduced pressure. To the resulting concentrated solution was cautiously added ether-saturated $\mathrm{HCl}$ gas. The white precipitate that formed was recovered and kept overnight in a vacuum desiccator; recrystallization from $\mathrm{MeOH}$ afforded $0.61 \mathrm{~g}(85 \%)$ of white crystals. Mp: $279-281^{\circ} \mathrm{C}$. Spectral data for the free base follows. IR (film): 1710 (CO cycloalkanone), 1678 (CO benzoyl). ${ }^{1} \mathrm{H}-\mathrm{NMR}$ $\left(\mathrm{CDCl}_{3}\right): \delta 8.04-7.93(\mathrm{~m}, 1 \mathrm{H}, \mathrm{H}-8), 7.49-742(\mathrm{dt}, 1 \mathrm{H}, \mathrm{H}-6)$, 7.337 .21 (m, 2H, H-5, H-7), 7.16-7.09 (dd, 2H o-Ph-F), 3.06$2.98\left(\mathrm{~m}, 4 \mathrm{H}, \mathrm{CH}_{2} \mathrm{CH}_{2} \mathrm{~N}\right.$ ), 2.62-1.62 (complex multiplet). Anal. $\left(\mathrm{C}_{24} \mathrm{H}_{26} \mathrm{NO}_{2} \mathrm{~F} \cdot \mathrm{HCl}\right) \mathrm{C}, \mathrm{H}, \mathrm{N}$.

Pharmacology. Drugs and Chemicals. All compounds were administered in $0.01 \mathrm{~mL} / \mathrm{g}$ injections (apomorphine subcutaneously and all others intraperitoneally). Compound 20 was administered as a suspension in $0.5 \%(\mathrm{w} / \mathrm{v})$ sodium carboxymethylcellulose (Merck); haloperidol (Sigma) and compounds 21 and 23 were dissolved in $1 \%$ lactic acid in water; dextroamphetamine sulfate (Sigma), atropine hydrochloride (Sigma), eserine (physostigmine) hemisulphate (Sigma), and compound 22 were prepared in saline; and apomorphine hydrochloride (Sigma) was dissolved in $0.9 \%$ saline solution with $1 \%$ ascorbic acid $(w / v)$ to prevent oxidation. Chemicals used for physiological solutions were of analytical grade.

Experimental Animals and Conditions. Male Charles River CD1 albino mice weighing $25 \pm 2 \mathrm{~g}$, male Wistar rats $(275 \pm 25 \mathrm{~g})$, and male Sprague-Dawley rats $(275 \pm 25 \mathrm{~g})$ were used. "In vivo" assays was carried out in a quiet room thermostated at $22 \pm 1{ }^{\circ} \mathrm{C}$ with a 12 -h light/dark cycle $(08.00-$ 20.00 ) and always at the same time of day (so as to avoid variation due to circadian rhythms). Food and tap water were free available in the home cage.

"In Vivo" Experiments. Locomotor Activity. Spontaneous locomotor activity was monitored in six groups of five mice during $1 \mathrm{~h}$ following administration of haloperidol, $\mathbf{2 1}$, or $\mathbf{2 3}$ at doses of 0.5 or $2.0 \mathrm{mg} / \mathrm{kg}, 20$ or 22 at doses of 2 or $8 \mathrm{mg} / \mathrm{kg}$, or vehicle alone. In experiments to determine amphetamineinduced hyperactivity, $5 \mathrm{mg} / \mathrm{kg}$ of dextroamphetamine sulfate was administered to 4-10 groups of three mice $30 \mathrm{~min}$ after administration of vehicle, haloperidol $(0.063,0.094,0.125$, or $0.5 \mathrm{mg} / \mathrm{kg}$ ), compound 23 at doses of 0.5 or $2 \mathrm{mg} / \mathrm{kg}, 21$ at a dose of $0.5 \mathrm{mg} / \mathrm{kg}$, or 20 or 22 at a dose of $8 \mathrm{mg} / \mathrm{kg}$. Both spontaneous and amphetamine-induced motor activity were recorded during the following hour in an activity cage (Panlab Actisystem D.A.S. 16 V.1), which contains an electromagnetic field that is sensitive to any motion within it.

Catalepsy. This was tested in mice $(n=15-30) 60 \mathrm{~min}$ after administration of vehicle, haloperidol $(0.25,0.5,0.8,1$, or $2 \mathrm{mg} / \mathrm{kg}$ ), compounds 21 or $23(0.5,2$ or $8 \mathrm{mg} / \mathrm{kg})$, or 20 or $22(2 \mathrm{or} 8 \mathrm{mg} / \mathrm{kg})$. The mice were placed with their forepaws on one horizontal wire and their hindpaws on another $6 \mathrm{~cm}$ away and $2 \mathrm{~cm}$ lower. The time during which the mouse maintained this position was recorded, and more than $30 \mathrm{~s}$ was considered to indicate catalepsy.

Eserine (Physostigmine)-Induced Mortality. Groups of 10 mice (two groups per compound and dosage level) were treated, $30 \mathrm{~min}$ before eserine injection $(2 \mathrm{mg} / \mathrm{kg})$, with vehicle, atropine $(4 \mathrm{mg} / \mathrm{kg})$, haloperidol, compounds 21 or $23(2 \mathrm{mg} /$ $\mathrm{kg}$ ), or 20 or $22(8 \mathrm{mg} / \mathrm{kg})$. The mice were placed in cages and deaths were counted $60 \mathrm{~min}$ after injection of eserine.

Apomorphine-Induced Climbing. The method of Protais $^{39}$ was used with a minor modification. The climbing behavior of mice was observed in individual cylindrical stainless-steel wire cages (diameter, $12 \mathrm{~cm}$; height, $14 \mathrm{~cm}$ ). Mice (six per compound and dosage, except for the control group, for which 12 animals were used) were treated with vehicle, haloperidol $(0.125-0.25 \mathrm{mg} / \mathrm{kg})$, or compounds 20,21 , or 23 $(0.5,2$, or $8 \mathrm{mg} / \mathrm{kg})$ or compound $22(2,8$, or $16 \mathrm{mg} / \mathrm{kg})$, and 30 min later with $2 \mathrm{mg} / \mathrm{kg}$ of apomorphine (subcutaneously). During the next $30 \mathrm{~min}$, climbing activity was recorded every $10 \mathrm{~min}$ using the following scale: 0 , four paws were on the floor; 1 , one or two paws were against the grid wall; and 2, 
the mouse clung to the grid wall with three or four paws. The scores recorded 20 and 30 min postapomorphine were added, and the mean of this sum was calculated for each group.

"In Vitro" Experiments. Male Wistar rats were killed by cervical dislocation and decapitation. Both striata and the frontal cortex were quickly dissected out on a cold plate, weighed, and stored at $-20^{\circ} \mathrm{C}$ until assay.

$\mathbf{D}_{2}$ Binding. For $\left[{ }^{3} \mathrm{H}\right]$ spiperone binding assays, paired striata were homogenized in 50 volumes of ice-cold $50 \mathrm{mM}$ Tris$\mathrm{HCl}$ with a Polytron (setting 6 for $5 \mathrm{~s}$ ) and then centrifuged at $40000 \mathrm{~g}$ for $10 \mathrm{~min}$ in a Sorvall centrifuge at $4{ }^{\circ} \mathrm{C}$. The pellet was resuspended and the process repeated. The final pellet was resuspended in 200 volumes of $50 \mathrm{mM}$ Tris- $\mathrm{HCl}$ buffer containing $120 \mathrm{mM} \mathrm{NaCl}$. Samples $(200 \mu \mathrm{L})$ of the final suspension were incubated for $10 \mathrm{~min}$ at $37^{\circ} \mathrm{C}$ with $25 \mu \mathrm{L}$ of displacing agent or its vehicle (10\% methanol) and $25 \mu \mathrm{L}$ of a solution of $\left[{ }^{3} \mathrm{H}\right]$ spiperone; the reaction was terminated by rapid vacuum filtration through Watman $\mathrm{GF} / \mathrm{C}$ filters, which were washed with $3 \times 5 \mathrm{~mL}$ of cold buffer. For equilibrium saturation analysis, six ligand concentrations from $0.05-1 \mathrm{nM}$ were used. Nonspecific binding was determined by addition of $10^{-5} \mathrm{M}(+)$-sulpiride. For determination of the $\mathrm{IC}_{50}$ values of drugs displacing $\left[{ }^{3} \mathrm{H}\right]$ spiperone $(0.25 \mathrm{nM})$ binding, at least six ascending concentrations of each drug were used $\left(10^{-9}\right.$ $10^{-4} \mathrm{M}$ ). Assays were carried out in triplicate at each ligand or displacing drug concentration.

D 1 Binding. For $\left[{ }^{3} \mathrm{H}\right] \mathrm{SCH} 23390$ binding assays, paired striata were homogenized in 200 volumes of $50 \mathrm{mM}$ Tris- $\mathrm{HCl}$ buffer and centrifuged at $1000 \mathrm{~g}$ for $10 \mathrm{~min}$, and the supernatant was centrifuged at $20000 \mathrm{~g}$ for $10 \mathrm{~min}$. The pellet was resuspended and the process repeated. The final pellet was resuspended in $50 \mathrm{mM}$ Tris- $\mathrm{HCl}$ containing $120 \mathrm{mM} \mathrm{NaCl}, 5$ $\mathrm{mM} \mathrm{KCl}, 2 \mathrm{mM} \mathrm{CaCl}_{2}$, and $1 \mathrm{mM} \mathrm{MgCl}_{2}$. Saturation curves were constructed with six ligand concentrations from 0.15 to $2.5 \mathrm{nM}$. Nonspecific binding was determined by addition of unlabeled SCH $23390\left(10^{-6} \mathrm{M}\right)$. Samples were incubated at $25^{\circ} \mathrm{C}$ for $30 \mathrm{~min}$.

5-HT ${ }_{2 A}$ Binding. Frontal cortex tissue was homogenized (Ultraturrax 5, s at $20000 \mathrm{rpm}$ ) in 50 volumes of $50 \mathrm{mM}$ Tris$\mathrm{HCl}, \mathrm{pH} 7.4$, and centrifuged at $30000 \mathrm{~g}$ for $10 \mathrm{~min}$ at $4{ }^{\circ} \mathrm{C}$. The pellet was rehomogenized and centrifuged again. The final pellet was reconstituted in 200 volumes of buffer. Aliquots of membrane preparations $(200 \mu \mathrm{L})$ were incubated with $25 \mu \mathrm{L}$ of $1 \mathrm{nM}\left[{ }^{3} \mathrm{H}\right]$ ketanserin $(\mathrm{NEN} 60 \mathrm{Ci} / \mathrm{mmol}$ ). Specific binding was defined by incorporation of $25 \mu \mathrm{L}$ of methysergide (final concentration $1 \mu \mathrm{M}$ ). Samples were incubated for $15 \mathrm{~min}$ at $37^{\circ} \mathrm{C}$, and incubation was terminated by vacuum filtration.

Aorta Ring Experiments. Endothelium-stripped aorta rings from Sprague-Dawley rats were mounted under a resting tension of $1.5 \mathrm{~g}$ in a $20-\mathrm{mL}$ organ bath containing Krebs solution (composition $(\mathrm{mM}): \mathrm{NaCl}, 118.07 ; \mathrm{KCl}, 4 ; \mathrm{CaCl}_{2} \mathrm{H}_{2} \mathrm{O}$, 2.5; $\mathrm{MgSO}_{4} \cdot 7 \mathrm{H}_{2} \mathrm{O}, 1.2 ; \mathrm{KH}_{2} \mathrm{PO}_{4}, 1.2 ; \mathrm{NaHCO}_{3}, 25 ;$ glucose, 11) at $37^{\circ} \mathrm{C}$ bubbled with carbogen $\left(95 \% \mathrm{O}_{2}, 5 \% \mathrm{CO}_{2}\right)$. Isometric contraction forces were measured using a CPUL 0-25-g transducer connected to a Celaster IOS-1 apparatus. After stabilization for $60 \mathrm{~min}$, cumulative concentration-response curves were constructed as per Van Rossum, ${ }^{40}$ increasing serotonin concentrations from $30 \mathrm{nM}$ to $10 \mathrm{mM}$ in the absence or in the presence of increasing concentrations of ketanserine or new compounds.

Expression of Results and Statistical Analysis. Pharmacological calculations were obtained by PCS program (Pharmacologic Calculation System).41 The statistical significance of differences between means was determined by Student's test for unpaired data, the differences with probabilities lower than 0.05 were considered statistically significant. Percentage change in locomotor activity (\% LC) was calculated as: \% LC $=[$ (mean no. of movements by control animals $)-$ (mean no. of movements by treated animals) $] /$ (mean no. of movements by control animals) $\times 100$. The percentage of animals showing catalepsy $(\% \mathrm{C}$ ) was calculated as (no. of animals showing catalepsy)/(total no. of animals $) \times 100 . E_{50}$ values were calculated by Litchfield and Wilcoxon's method in the catalepsy test.

Inhibition constant $\left(K_{\mathrm{j}}\right)$ values were calculated from the Cheng-Prussof equation: $K_{\mathrm{i}}=\mathrm{IC}_{50} /\left[1+\left(F / K_{\mathrm{D}}\right)\right]$, where $F$ is the total concentration of ${ }^{3} \mathrm{H}$-ligand used, $K_{\mathrm{D}}$ is the equilibrium dissociation constant, and $\mathrm{IC}_{50}$ is the drug concentration required to inhibit 50\% of specific binding. ${ }^{42}$ Percentage specific binding was calculated as [(dpm sample) - (dpm nonspecific binding $)] /(\mathrm{dpm}$ total binding $)-(\mathrm{dpm}$ nonspecific binding) $] \times 100$. Competitive antagonism was quantified as $\mathrm{p} A_{2}$, which was calculated from a Schild plot of log (dose ratio - 1) for three antagonist concentrations; six replicate experiments were performed.

Molecular Modeling. The geometries of molecular fragments were optimized by the AM1 method ${ }^{43}$ as implemented in the program MOPAC. ${ }^{44}$ For both these computations and structural fitting, the molecular modeling package BIOSYM Inc., San Diego, CA, was used.

Acknowledgment. This work was partially supported by the Spanish Interministerial Comision on Science and Technology (CICYT) under Grants SAF920957-C02-01 and FAR91-1072-C03 and by the Xunta de Galicia under Grant XUGA 20308B92. We also thank SANAL for a grant to C. F. Masaguer, and the Xunta de Galicia for grants to J. Fueyo, C. F. Masaguer, M. E. Castro, and E. Rosa.

\section{References}

(1) Coward, D. M.; Imperato, A.; Urwyler, S.; White, T. G. Biochemical and behavioural properties of clozapine. Psychopharmacology 1989, 99, 6-12.

(2) Fitton, A.; Heel, R. C. Clozapine. A review of its pharmacological properties, and therapeutic use in schizophrenia. Drugs $\mathbf{1 9 9 0}$, $40(5), 722-747$.

(3) Meltzer, H. Y. Clozapine: Mechanism of action in relation to its clinical advantages. In Recent Advances in Schizophrenia; Kales, A., Stefanis, D. N., Talbott, J., Eds.; Springer-Verlag: New York, 1990; pp 237-256.

(4) Seeman, P.; Grigoriades, D.; Niznik, H. B. Selectivity of agonists and antagonists at D-2 dopamine receptors compared to D-1 and S-2 receptors. Drug. Dev. Res. 1986, 9, 63-69.

(5) Seeman, P.; Chou-Wong, M.; Tadesco, J.; Wong, K. Antipsychotic drug doses and neuroleptic/dopamine receptors. Nature 1976 $261,717-719$.

(6) Seeman, P.; Lee, T. Antipsychotic drugs: direct correlation between clinical potency and presynaptic action on dopamine neurons. Science 1975, 188, 184-189.

(7) Iorio, L. C.; Barnett, A.; Leitz, F. H.; Houser, V. P.; Korduba, C. A. J. SCH23390, a potential benzazepine antipsychotic with unique interactions on dopaminergic systems. J. Pharmacol. Exp. Ther. 1983, 226, 462-468.

(8) Clark, D.; White, F. G. Review: $D_{1}$ dopamine receptor-the search for a function. Synapse 1987, 1, 347-388.

(9) Morelli, M.; Di Chiara, G. Catalepsy induced by SCH 23390 in rats. Eur. J. Pharmacol. 1985, 117, 179-185.

(10) Civelli, O.; Bunzow, J. R.; Grandy, D. K.; Zhou, Q. Y.; Van Tol, H. M. M. Molecular biology of the dopamine receptors. Eur. J. Pharmacol. 1991, 207, 277-286.

(11) Sibley, D. R.; Monsma, F. J., Jr. Molecular biology of dopamine receptors. Trends Pharmacol. Sci. 1992, 13, 61-69.

(12) Gingrich, J. A.; Caron, M. G. Recent advances in the molecular biology of dopamine receptors. Annu. Rev. Neurosci. 1993, 16, 299-321.

(13) Civelli, O.; Bunzow, J. R.; Grandy, D. K. Molecular diversity of the dopamine receptors. Annu. Rev. Pharmacol. Toxicol. 1993, $32,281-307$.

(14) Meltzer, H. Y. Clinical studies on the mechanism of action of clozapine: the dopamine-serotonin hypothesis of schizophrenia. Psychopharmacology 1989, 99, 18-27.

(15) Gelders, Y. G. Thymostenic agents. A novel approach in the treatment of schizophrenia. Br. J. Psych. 1989, 155 (5), 33-36.

(16) Cortizo, L.; Santana, L.; Raviña, E.; Orallo, F.; Fontenla, J. A. Castro, E.; Calleja, J. M.; de Ceballos, M. L. Synthesis and antidopaminergic activity of some 3-(aminomethyl)tetralones as analogues of butyrophenone. J. Med. Chem. 1991, 34, 22422247.

(17) Loza, M.; Verde, I.; Castro, M. E.; Orallo, F.; Fontenla, J. A.; Calleja, J. M.; Raviña, E.; Cortizo, E.; de Ceballos, M. 5-HT2 antagonist activity of some 3-aminomethyltetralones. Bioorg. Med. Chem. Lett. 1991, 1 (12), 7171-720.

(18) Boswell, R. F; Welstead, W. J.; Duncan, R. C.; Funderburk, W. H. [1-[3-Phenothiazin-10-yl-propyl]-4-piperidinyl phenylmethanones, a novel class of long-acting neuroleptic agents. J. Med. Chem. 1978, 21, 136-139. 
(19) Herndon, J. L.; Ismaiel, A.; Ingher, S. P.; Teitler, M.; Glennon, R. A. Ketanserin analogues: structure-affinity relationships for 5-HT $\mathrm{H}_{2}$ and $5-\mathrm{HT}_{1 \mathrm{c}}$ serotonin receptor binding. J. Med. Chem. 1992, 35, 4903-4910.

(20) Newman, M. S.; Sagar, W. C.; Cochrane, C. C. A new method for introducing a two carbon acid side chain into ketones. J. Org. Chem. 1958, 23, 1832-1835.

(21) Cignarella, G.; Barlocco, D.; Landriani, L.; Folloni, M.; Pinna, G. A.; Sala, F.; Germini, M. New congeners of antihypertensive and antithrombotic 7-amino or 7-acetyl-aminosubstituted-4,4adihydro-5H-indeno[1,2-c]pyridazin-3-ones. Il Farmaco. Ed.Sc. 1988, 43, 169-179.

(22) Bachmann, W. E.; Thomas, D. G. The synthesis of analogs of the sex hormones. An analog of equilenin lacking the phenolic A ring. J. Am. Chem. Soc. 1941, 63, 598-602.

(23) Bachmann, W. E.; Johnson, G. D. 3-ketohydrophenantrenes and 2-ketohydro-1,2-cyclopentenonaphthalenes. J.Am. Chem. Soc. 1949, 71, 3463-3467.

(24) Groves, L. H.; Swan, G. A. Indene series. Part II. A Synthesis of 1,2,3,4,8,10-hexahydro-2-ketocyclopent[a]indene. J. Chem. Soc. 1951, 867-872.

(25) Djerassi, C.; Pettit, G. R.; Herald, D. L.; Sanson, D. R. Arylmagnesium bromide additions to tetralone-2-acetic acid followed by catalytic hydrogenolysis: stereochemical consequences. $J$. Org. Chem. 1991, 56, 5360-5368.

(26) Cignarella, G.; Grella, G.; Loriga, M.; Curzu, M. M.; Schiatti, G. Inatessa attivitá antiifiamatoria di strutture rigida derivative da 6-arilpiridazinoni antiipertensive. Sintesi e attivitá di 4,4adiidro-5H-indeno[1,2-c]piridazin-3-oni. Il Farmaco. Ed. Sc. 1978, 33, 866-874.

(27) Loza, M. G-Ferreiro, T. Sanz, F; Lozoya, E.; Rodriguez, J.; Manaut, F. Verde, I.; Castro, E.; Fontenla, J. A.; Cadavid, I.; Honrubia, M.; Fueyo, J. Raviña, E. Antiserotoninergic activity of 2-aminoethylbenzocyclanones in rat aorta: structure-activity relationships. J. Pharm. Sci, 1993, 82 (5), 513-517.

(28) Meltzer, H. Y.; Matsubara, S.; Lee, J. C. Classification of typical and atypical antipsychotic drugs on the basis of dopamine D-1, D-2 and serotonin2 $\mathrm{pK}_{\mathrm{i}}$ values. J. Pharmacol. Exp. Ther. 1989, $25(1), 238-251$.

(29) Meltzer, H. Y.; Matsubara, S.; Lee, J. C. The ratios of serotonin2 and dopamine2 affinities differentiate atypical and typical antipsychotic drugs. Psychopharmacol. Bull. 1989, 25 (3), 390392.

(30) Ferris, R. M.; Harfenist, M.; McKenzie, G. M.; Cooper, B.; Soroko F. E.; Maxwell, R. A. BW 234U, (cis-9-[3-(3,5-dimethyl-1-piperazinyl)propyl]carbazole dihydrochloride): a novel antipsychotic agent. J. Pharm. Pharmacol. 1982, 34, 388-390.
(31) Hyttel, J.; Arnt, J.; Berghe, M. V. D. Selective dopamine $D_{1}$ and $\mathrm{D}_{2}$ receptor antagonist. In Clinical Pharmacology in Psychiatry; Dahl, S. G., Gram, L. F., Eds.; Springer-Verlag: Berlin, 1989; pp 109-122.

(32) Arnt, J.; Christensen, A. V.; Hyttel, J. Differential reversal by scopolamine of effects of neuroleptics in rats. Relevance for evaluation of therapeutic and extrapyramidal side effect potential. Neuropharmacology 1981, 20, 1331-1334.

(33) Bruhwyler, J.; Chleide, E.; Mercier, M. Clozapine: An atypical neuroleptic. Neurosci. Biobehav. Rev. 1990, 14 (4), 357-363.

(34) Reynols, G. P. Developments in the drug treatment of schizophrenia. Trends Pharmacol. Sci. 1992, 31, 116-121.

(35) Perregaard, J.; Arnt, J.; Bogeso, K. P.; Hyttel, J.; Sánchez, C. Noncataleptogenic, centrally acting dopamine D-2 and serotonin 5-HT $\mathrm{H}_{2}$ antagonists within a series of 3-substituted 1-(4-fluorophenyl)-1H-indoles. J. Med. Chem. 1992, 35, 1092-1101.

(36) Maitre, M.; Hechler, V.; Vayer, P.; Gobaille, S.; Cash, C. D.; Schmitt, M.; Bourguignon, J. J. A specific 9-hydroxybutyrate receptor ligand possesses both antagonistic and anticonvulsivant properties. J. Pharmacol. Exp. Ther. 1990, 225, 657-663.

(37) Hardegger, B.; Shatzmiller, S. Synthesis with 1,2-oxazines I. Synthesis of 4,5-dihydro-6H-1,2-oxazin-6-one derivatives. Helv. Chim. Acta 1976, 59, 2499-2502.

(38) Barlocco, D.; Pinna, G. A.; Carboni, L.; Cipolla, P. Synthesis and pharmacological study of 4,4a,5,6-tetrahydro-4a-substitutedbenzo[h]cinnolin-3(2H)ones. Il Farmaco 1989, 44, 967-974.

(39) Protais, P.; Costentin, J.; Schwartz, J. C. Climbing behavior induced by apomorphine in mice: A simple test for the study of dopamine receptors in striatum. Psychopharmacology 1976, 50, $1-6$.

(40) Van Rossum, J. M. Cumulative dose-response curves III. Technique for the making of dose-response curves in isolated organs and the evaluation of drug parameters. Arch. Int. Pharmacodyn. $1963,143,299-330$.

(41) Tallarida, R. J.; Murray, R. B. Manual of Pharmacologic calculations with computer programs, 2th ed.; Tallarida, R. J., Ed.; Springer-Verlag: New York, 1987.

(42) Cheng, Y. C.; Prusoff, W. Relationship between the inhibition constant $(\mathrm{Ki})$ and the concentration of inhibitor which caused 50 per cent inhibition $\left(\mathrm{IC}_{50}\right.$ ) of an enzymatic reaction. Biochem. Pharmacol. 1973, 22, 3099-3108.

(43) Dawar, M. J. S.; Zoebish, E. G.; Healy, E. F.; Stewart, J. J. P AM1: a new general purpose quantum mechanical molecular model. J. Am. Chem. Soc. 1985, 107, 3902-3909.

(44) Stewart, J. J. P. MOPAC: a semiempirical molecular orbital program. J. Comput.-Aided Mol. Des. 1990, 4, 1-105. 